\title{
ANALISIS KELAINAN JANTUNG MENGGUNAKAN DIMENSI FRAKTAL DAN TRANSFORMASI WAVELET
}

\author{
D. R. Oktaviani ${ }^{1}$ dan M. Habiburrohman² \\ 1 UIN Walisongo Semarang \\ 2Universitas Ivet Semarang \\ 1dinni@walisongo.ac.id, 2muhammadhabiburrohmanmh99@gmail.com
}

\begin{abstract}
The disease that causes the largest number of deaths in Indonesia to date is acute coronary syndrome or called the silence killer. Deaths due to coronary heart disease (CHD) reached $26.4 \%$. Therefore, to prevent the high death rate from $\mathrm{CHD}$, early detection of $\mathrm{CHD}$ can be done. One way that can be done is checking the ECG (electrocardiogram / electrocardiograph) record. Then by using the HRV (Heart Rate Variability) method, which is to analyze the ECG signal which can take measurements, physiological interpretation, and clinical use of the ECG signal so that it can find out an arrhythmia (a condition in which the heart beats erratically) a person's heart and take medical steps right. In this article using wavelet transform analysis to identify heart disease. The results are then compared with the fractal dimensions of the heart rate signal. FD identifies heart disease with more than $90 \%$ confidence
\end{abstract}

Keywords : Fractal, Heart, Wavelet.

\section{ABSTRAK}

Penyakit yang menyebabkan kematian terbesar di Indonesia sampai saat ini adalah jantung koroner atau disebut the silence killer. Kematian akibat penyakit jantung koroner (PJK) mencapai 26,4\%. Oleh karena itu, untuk mencegah tingginya angka kematian akibat PJK, dapat dilakukan deteksi dini PJK. Salah satu cara yang dapat dilakukan adalah pemeriksaan rekaman EKG (elektrokardiogram/electrocardiograph). Kemudian dengan menggunakan metode HRV (Heart Rate Variability) yaitu untuk menganalisa sinyal EKG yang dapat melakukan pengukuran, interpretasi fisiologi, dan penggunaan klinis pada sinyal EKG sehingga dapat mengetahui aritmia (suatu kondisi di mana jantung berdenyut tidak menentu) jantung seseorang dan mengambil langkah medis yang tepat. Pada artikel ini akan menggunakan analisisis transformasi wavelet pada untuk mengidentitifkasi penyakit jantung. Kemudian hasilnya akan dibandingkan dengan dimensi fraktal dari signal detak jantung. FD mengidentifikasi penyakit jantung dengan keyakinan lebih dari $90 \%$.

Kata kunci : Fraktal, Jantung, Wavelet. 


\section{PENDAHULUAN}

Indonesia saat ini menghadapi masalah kesehatan yang kompleks dan beragam. Mulai dari demam berdarah sampai penyakit pernapasan akut akibat virus corona yang terjadi saat ini. Selain penyakit tersebut, ada penyakit lainnya yang menyebabkan kematian terbesar di Indonesia sampai sekarang yakni penyakit jantung koroner (acute coronary syndrome) atau disebut the silence killer. Angka kematian di Indonesia akibat penyakit jantung koroner (PJK) mencapai 26,4\%. Oleh karena itu, untuk mencegah tingginya angka kematian akibat PJK, dapat dilakukan deteksi dini PJK. Salah satu cara yang dapat dilakukan adalah pemeriksaan rekaman EKG (elektrokardiogram/ electrocardiograph), atau pemeriksaan echocardiograph (pemeriksaan jantung dengan alat ultrasonografi (USG)).

Bio-sinyal pada dasarnya non-stasioner, yang menampilkan fraktal self-similarity. Bio-sinyal berisi indikator penyakit saat ini, atau bahkan peringatan tentang akan datangnya suatu penyakit. Indikator tersebut dapat hadir setiap saat atau dapat terjadi secara acak dalam skala waktu. Namun, untuk menunjukkan anomali (penyimpangan atau keanehan yang terjadi atau dengan kata lain tidak seperti biasanya) membutuhkan waktu beberapa jam, sehingga dirasa berat dan memakan waktu. Oleh karena itu, alat analisis berbasis komputer sangat berguna dalam diagnostik.

EKG termasuk salah satu bio-sinyal. EKG terdiri dari gelombang $P$, kompleks $Q R S$, dan gelombang T (Lusiana Utari, 2016). Denyut jantung dari individu yang sehat tidak konstan bahkan dalam kondisi tenang, dan terus berubah sepanjang hari, yang dapat dipantau secara langsung dari EKG. Penyakit dan penderitaan yang dialami memberikan pengaruh terhadap denyut jantung, dan oleh karena itu, pola dan rentang variabilitas detak jantung mengandung informasi penting tentang ketahanan tubuh, jenis penyakit, dll. Oleh karena itu, klasifikasi berdasarkan penyebaran dan pola dari parameter ini dapat memberikan wawasan yang berguna tentang jenis dan intensitas penderitaan yang dialami seseorang.

Pada tahun 1996, Perkumpulan para dokter ahli jantung di Eropa atau Task Force of The European Society of Cardiology and The North American Society of Pacing and Electrophysiology yang melibatkan para ahli kesehatan, teknik, matematika dan fisiologis mengeluarkan suatu pedoman standar pengukuran, interpretasi fisiologi, dan penggunaan klinis (standard of measurement, physiological interpretation, and clinical use) untuk analisa sinyal EKG yang dinamakan HRV (Heart Rate Variability) (Halomoan, 2013). Dengan menggunakan metoda HRV, seseorang dapat diketahui perubahan aktivitas jantungnya dan dianalisa untuk menginterpretasikan keadaan jantung. Analisa EKG dengan metoda HRV berfokus terhadap perubahan osilasi interval waktu detak jantung yang berurutan dan kecepatan detak jantung. Oleh sebab itu HRV atau heart rate variability digunakan untuk menggambarkan variasi interval RR dan kecepatan detak jantung. 
Penggunaan metode HRV (Heart Rate Variability) yaitu untuk menganalisa sinyal EKG yang dapat melakukan pengukuran, interpretasi fisiologi, dan penggunaan klinis pada sinyal EKG sehingga dapat mengetahui aritmia (suatu kondisi di mana jantung berdenyut tidak menentu) jantung seseorang dan mengambil langkah medis yang tepat.

Artikel ini menggunakan variabilitas detak jantung sebagai sinyal dasar untuk analisis waktu wavelet kontinu. Pola yang muncul dibandingkan dengan jenis penyakit yang diketahui. Dimensi fraktal (FD) dari sinyal HRV dibandingkan dengan pola transformasi wavelet. FD memiliki rentang unik untuk setiap jenis penyakit.

\section{METODE PENELITIAN}

\subsection{Data}

Data EKG untuk analisis diperoleh dari MIT-BIH aritmia database. Sebelum direkam, sinyal EKG diproses untuk menghilangkan kebisingan karena kekuatan gangguan, respirasi, tremor otot, paku dll. Rincian dari data EKG masing-masing kelas dapat dilihat pada Tabel 1.

Tabel 1 : Rincian Data dari Masing-masing Kelas

\begin{tabular}{|c|c|c|c|c|c|c|}
\hline Kelas & NSR & PVC & CHB & SSS & Ischemic & AF \\
\hline Banyak data & 60 & 60 & 20 & 20 & 20 & 35 \\
\hline
\end{tabular}

(Sumber data: MIT-BIH aritmia database)

Menurut Junartho pada artikel yang berjudul analisa sinyal EKG dengan metode HRV (Heart Rate Variability) pada domain waktu aktivitas berdiri dan terlentang tahun 2013, Interval antara dua QRS kompleks berturut - turut didefinisikan sebagai interval $R R(t k-R)$ dan denyut jantung (denyut per menit) diberikan sebagai:

$$
H R=60 / t_{r-r}
$$

Dalam artikel ini, upaya yang dilakukan adalah untuk mengkarakterisasi dan mengklasifikasikan enam kelas yang berbeda dengan satu kelas normal (NSR) dan lima penyakit jantung yang berbeda (PVC, CHB, SSS, Ischemic/dilated, AF) (Kuang Chua, 2012) . Sinyal HRV diekstrak dari Sinyal EKG untuk masing-masing kelas.

\subsection{Hardware dan Spesifikasi Perangkat Lunak}

Untuk menghitung denyut jantung dan program FD ini ditulis di MATLAB. CWT yang ditampilkan pada Bagian 3.1 diperoleh dari toollkit wavelet pada MATLAB versi 7.8. 


\subsection{Metode Penelitian}

Untuk transformasi wavelet dengan memasukkan data yang kemudian diolah dengan menggunakan toolkit wavelet pada MATLAB versi 7.8. Hasil pengolahan EKG dengan mengguakan toolkit Matlab tersebut dapat digambarkan melalu scalogram. Sementara untuk menghitung dimensi fraktal menggunakan dua algoritma yaitu algoritma Higuchi dan algoritma Katz.

\section{Algoritma Higuchi}

Algoritma Higuchi mengukur dimensi fraktal barisan waktu diskrit secara langsung dari deret waktu $\left\{x_{1}, x_{2}, x_{3}, \ldots, x_{n}\right\}$. Algoritma di bawah ini digunakan menghitung panjang $L_{m}(k)$ untuk setiap nilai $m$ dan $k$, dimana $m$ adalah waktu awal $\{m=1,2, \ldots, k\}$ dan $k$ adalah interval waktu $\left\{k=1,2, \ldots, k_{\max }\right\}$. $N$ adalah panjang sinyal sampel.

$$
L_{m}(k)=\frac{\sum_{i=1}^{\left\lfloor\frac{N-m}{k}\right]}|x(m+i k)-x(m+(i-1)) k|(N-1)}{\left\lfloor\frac{N-m}{k}\right\rfloor k}
$$

Setelah itu, jumlah total panjang $L_{m}(k)$ untuk setiap $k$ ditentukan oleh:

$$
L(k)=\sum_{m=1}^{k} L_{m}(k)
$$

Dan terakhir kemiringan kurva $\ln (L(k)) / \ln (1 / k)$ diestimasi menggunakan kuadrat linier yang paling cocok. Dan hasilnya adalah dimensi fraktal Higuchi (Higuchi, 1988).

\section{Algoritma Katz}

Dengan menggunakan metode Katz (Katz, 1988), dimensi fraktal dari suatu kurva dapat didefinisikan sebagai:

$$
D^{K a t z}=\frac{\log _{10}(L)}{\log _{10}(d)}
$$

Dimana $L$ adalah panjang total kurva atau jumlah jarak antara titik-titik berurutan, dan $d$ adalah diameter yang diperkirakan sebagai jarak antara titik pertama dan titik dari deret tersebut yang menjadi jarak terjauh. Secara matematis, $d$ dapat dinyatakan sebagai $d=$ $\max (\|x(1), x(i)\|)$.

Dimensi fraktal dihitung dengan cara ini tergantung pada satuan pengukuran yang digunakan. Jika unit satuannya berbeda, maka nilai dimensi fraktalnya juga berbeda. Pendekatan Katz memecahkan masalah ini dengan menciptakan unit umum atau tolak ukur: rata-rata jarak antara titik berurutan, a. Normalisasi Jarak $D$ tersebut adalah: 


$$
D^{K a t z}=\frac{\log _{10}(L / a)}{\log _{10}(d / a)}
$$

Definisikan $n=L / a$, dan dimensi Katz dapat ditulis sebagai berikut:

$$
D^{K a t z}=\frac{\log _{10}(n)}{\log _{10}\left(\frac{d}{L}\right)+\log _{10}(n)}
$$

\section{HASIL DAN PEMBAHASAN}

\subsection{Hasil}

Hasil scalograms wavelet, untuk berbagai jenis penyakit ditunjukkan pada Gambar. 1-

6. Dan hasil dari FD untuk berbagai jenis subjek yang tercantum dalam Tabel 2.

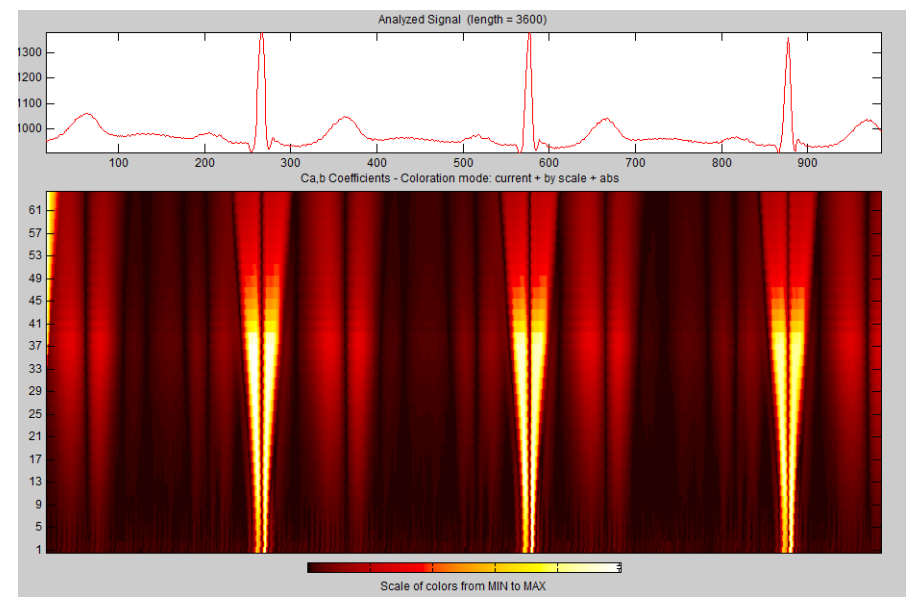

Gambar 1 : Scalograms NSR (Normal Sinus Rhythm)

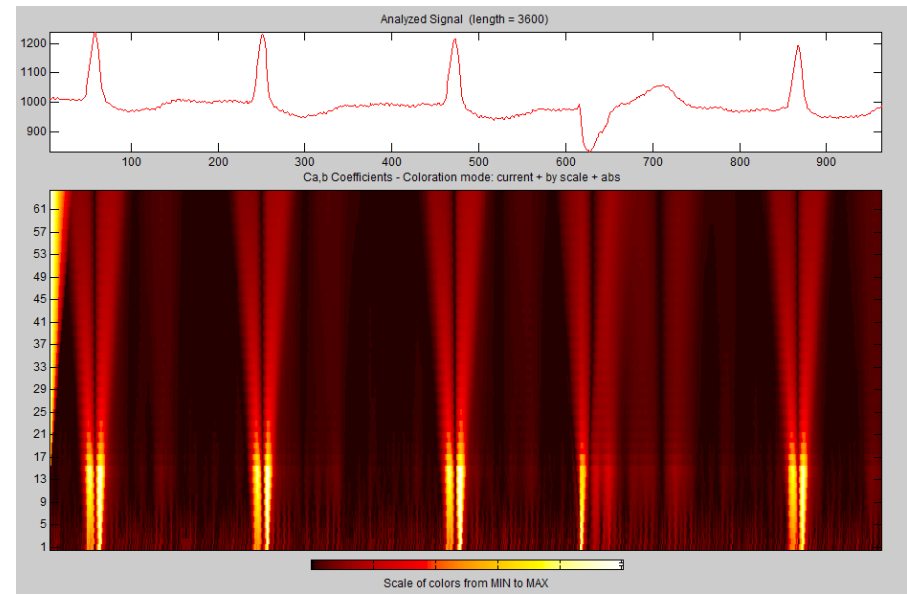

Gambar 2 : Scalograms PVC (Premature Ventricle Contractions) 


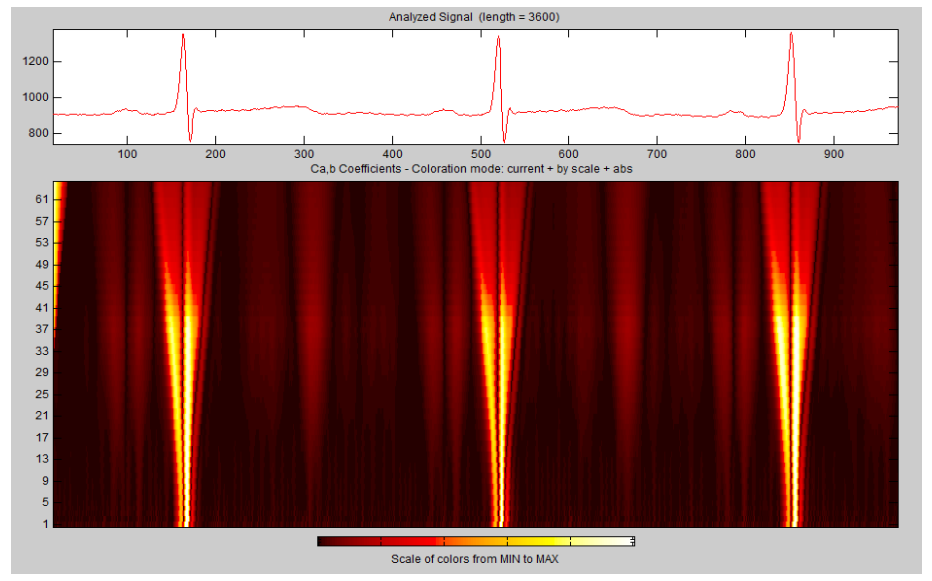

Gambar 3 : Scalograms AF (Atrial Fibrillation)

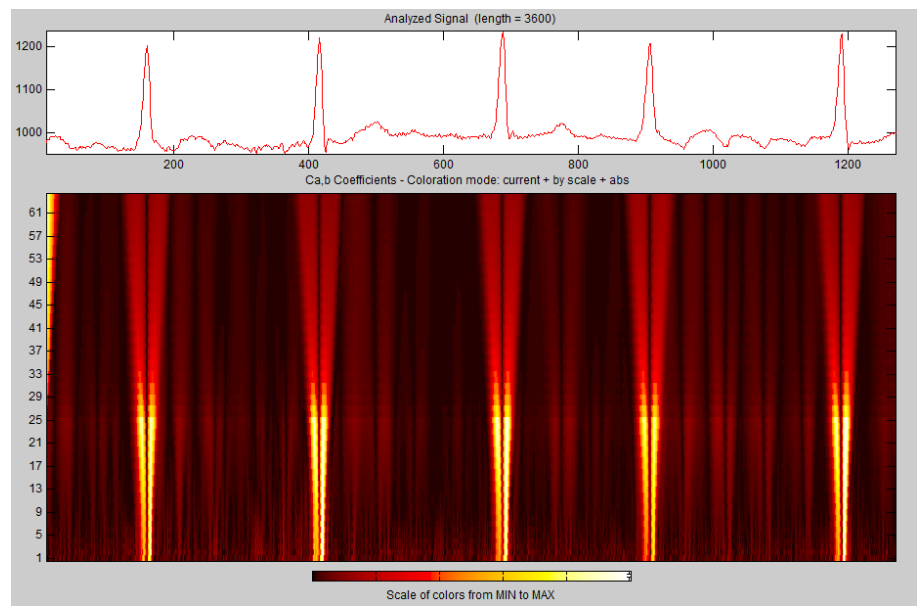

Gambar 4 : Scalograms CHB (Complete Heart Block)

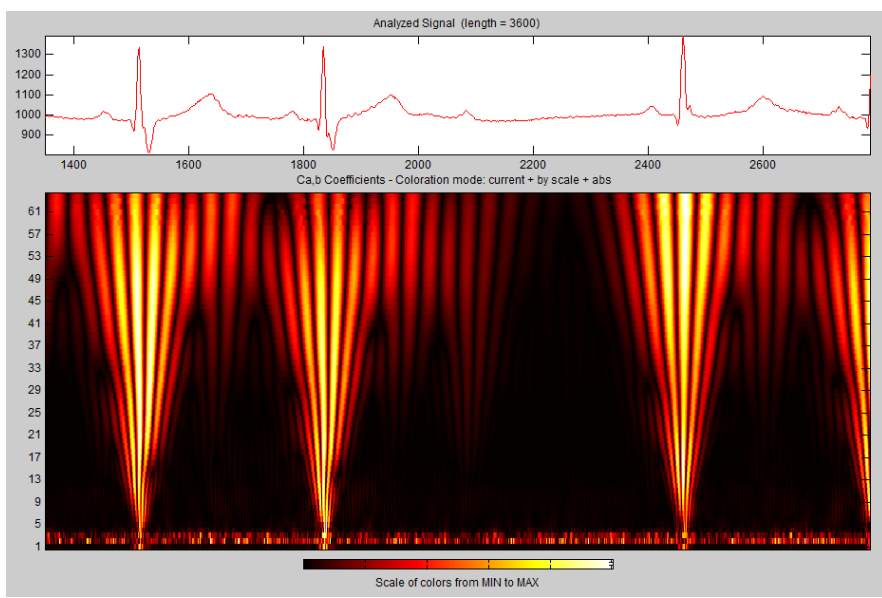

Gambar 5 : Scalograms SSS (Sick Sinus Syndrome) 


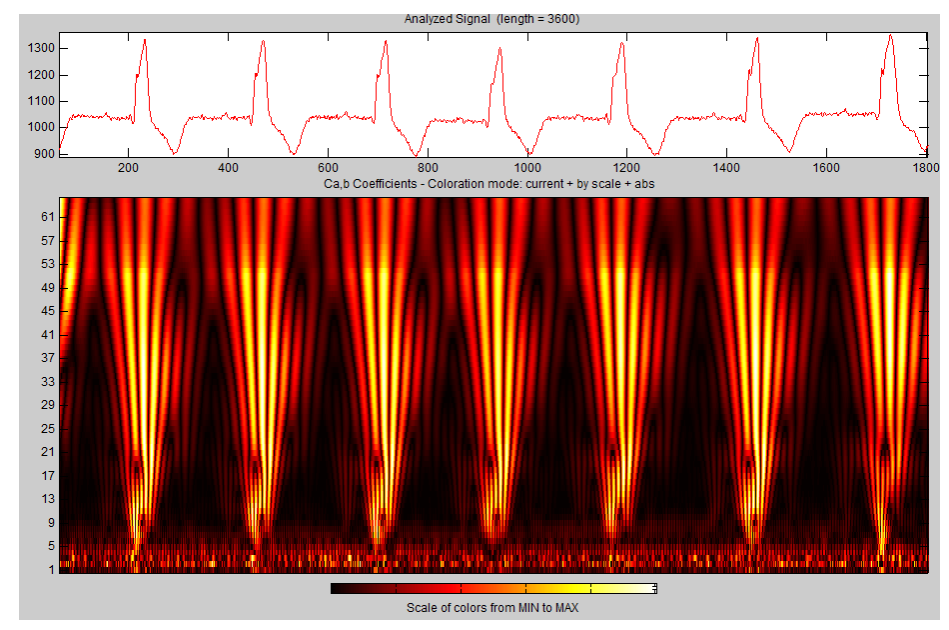

Gambar 6 : Scalograms Ischemic (Ischemic Cardiomyopathy)

Pada plot CWT yang ditampilkan, warna putih menunjukkan nilai yang tinggi dari koefisien (wavelet) dan hitam menunjukkan nilai yang rendah. Seperti dapat dilihat dalam gambar, pola tersebut menunjukkan kesinambungan pada pola yang menunjukkan variasi kontinu dari denyut jantung. Untuk kasus normal, pola CWT tampak teratur (Gambar 1). Dalam kelainan jantung jenis PVC terjadi penurunan tiba-tiba pada denyut jantung. Hal ini mungkin disebabkan denyut Pra-ventrikel dalam sinyal ECG (Gambar 2). Bagian hitam menunjukkan Bradikardia dan sisanya adalah normal. Di Atrial Fibrillation (AF), catatan sinyal detak jantung yang sangat variabilitas menentu; ini digambarkan sebagai perubahan mendadak dalam warna (Gambar 3). Dalam Complete Heart Block (CHB) kasus sebagai simpul gagal untuk mengirim sinyal-sinyal listrik berirama ke ventrikel, denyut jantung tetap rendah. Polanya didominasi dengan merah (nilai koefisien rendah) dengan sedikit perubahan intensitas warna (Gambar 4). Dalam Sick Sinus Syndrome-III (SSS-III, Bradikardia-Takikardia) ada variasi kontinu denyut jantung antara Bradikardia dan Takikardia, yang muncul dengan cara bergantian bercak hitam (Brady) dan pola berwarna (tachy) (Gambar 5). Dalam kasus iskemik / cardiomyopathy melebar, ventrikel tidak dapat memompa keluar darah ke tingkat normal. Di sini HRV sangat kecil. Sejalan dengan itu, variasi warna juga bertahap dan berkala (Gambar 6).

Dalam kasus $\mathrm{CHB}$, dimensi fraktal $\mathrm{FD}_{1}=1,24 \pm 0,042$ dan $\mathrm{FD}_{2}=1,41 \pm 0,033$ nilai sedikit rendah, menunjukkan variasi rendah dalam data denyut jantung. Dalam Iskemik kardiomiopati, variasi antara denyut jantung berurutan adalah rendah $\left(F D_{1}=1,32 \pm 0,024\right.$ dan $\mathrm{FD}_{2}=1,52 \pm$ 0,017). Untuk SSS-III, FD rendah $\left(F D_{1}=1,21 \pm 0,021\right.$ dan $\left.\mathrm{FD}_{2}=1,36 \pm 0,017\right)$ menunjukkan periodisitas yang melekat, untuk $A F$ memiliki terlalu banyak variasi dalam data denyut jantung $\left(F D_{1}=1,21 \pm 0,036\right.$ dan $\left.\mathrm{FD}_{2}=1,39 \pm 0,011\right)$. $\mathrm{PVC}$ memiliki denyut jantung tinggi $\left(F D_{1}=1,19\right.$ $\pm 0,043$ dan $\left.\mathrm{FD}_{2}=1,31 \pm 0,019\right)$, terakhir, untuk subjek normal memiliki variasi pada denyut jantung mereka $\left(F D_{1}=1,36 \pm 0,043\right.$ dan $\left.\mathrm{FD}_{2}=1,58 \pm 0,016\right)$. Untuk $\mathrm{CHB}$ dan iskemik $/$ 
cardiomyopathy membesar, FD ini turun dari FD subjek normal karena variasi R-R rendah. Dan untuk AF, SSS dan PVC, nilai FD ini jatuh lebih jauh, karena variasi R-R masing-masing menjadi tidak menentu.

Tabel 2 : Daftar Dimensi Fraktal (FD) dari Keenam Klasifikasi Data

\begin{tabular}{|c|c|c|c|c|c|c|c|}
\hline Type & NSR & PVC & AF & CHB & SSS & Ischemic & P value \\
\hline$D^{\text {Higuchi }}$ & $1,36 \pm 0,043$ & $1,19 \pm 0,043$ & $1,21 \pm 0,036$ & $1,24 \pm$ & $1,21 \pm$ & $1,32 \pm 0,024$ & 0,072 \\
(FD1) & & & & 0,042 & 0,021 & & \\
\hline D Katz $^{\text {(FD2) }}$ & $1,58 \pm 0,016$ & $1,31 \pm 0,019$ & $1,39 \pm 0,023$ & $1,41 \pm$ & $1,36 \pm$ & $1,52 \pm 0,017$ & 0,046 \\
(FD & & & & 0,033 & 0,011 & & \\
\hline
\end{tabular}

\section{KESIMPULAN}

Sinyal variabilitas denyut jantung (HRV) dapat digunakan sebagai indikator handal penyakit jantung. Sebuah scalogram CWT dari sinyal HRV dapat memberikan pola visual, yang dapat memberikan cukup wawasan sifat dan pola penyakit. Pola scalogram tergantung pada jenis wavelet yang digunakan untuk analisis.

Dari hasil penelitian dapat dilihat bahwa dimensi fraktal $D^{\text {higuchi }}$ dan $D^{\text {Katz }}$ untuk berbagai kelainan jantung menurun dibandingkan dengan yang normal. Hal ini menunjukkan bahwa ketidakteraturan sinyal HRV lebih sedikit untuk kelainan jantung. Dengan demikian, FD dapat digunakan sebagai indikator yang dapat diandalkan penyakit jantung dengan tingkat kepercayaan lebih dari $90 \%$. Angka kepercayaan yang lebih besar dari $90 \%$ tersebut diperoleh dari nilai $p$-value di tabel 2. P-value adalah nilai kesalahan maksimum yang diperoleh dari hasil perhitungan data.

\section{DAFTAR PUSTAKA}

[1] Halomoan, J., Analisa Sinyal EKG Dengan Metoda HRV ( Heart Rate Variability ) Pada Domain Waktu Aktivitas Berdiri Dan Terlentang, Seminar Nasional Aplikasi Teknologi Informasi (SNATI), 2013, pp. 29-35.

[2] Higuchi, T. Approach To An Irregular Time Series On The Basis Of The Fractal Theory, Physica D: Nonlinear Phenomena, 1988, doi: 10.1016/0167-2789(88)90081-4.

[3] Katz, M. J., Fractals And The Analysis Of Waveforms, Computers in Biology and Medicine,1988, doi: 10.1016/0010-4825(88)90041-8.

[4] Kuang Chua, C., Cardiac Health Diagnosis Using Higher Order Spectra and Support Vector Machine, The Open Medical Informatics Journal, 2012, doi: 10.2174/1874431101003010001.

[5] Lusiana Utari, E., Analisa Deteksi Gelombang Qrs Untuk Menentukan Kelainan Fungsi Kerja Jantung, 2016, Teknoin, 22(1), pp. 27-37. 